
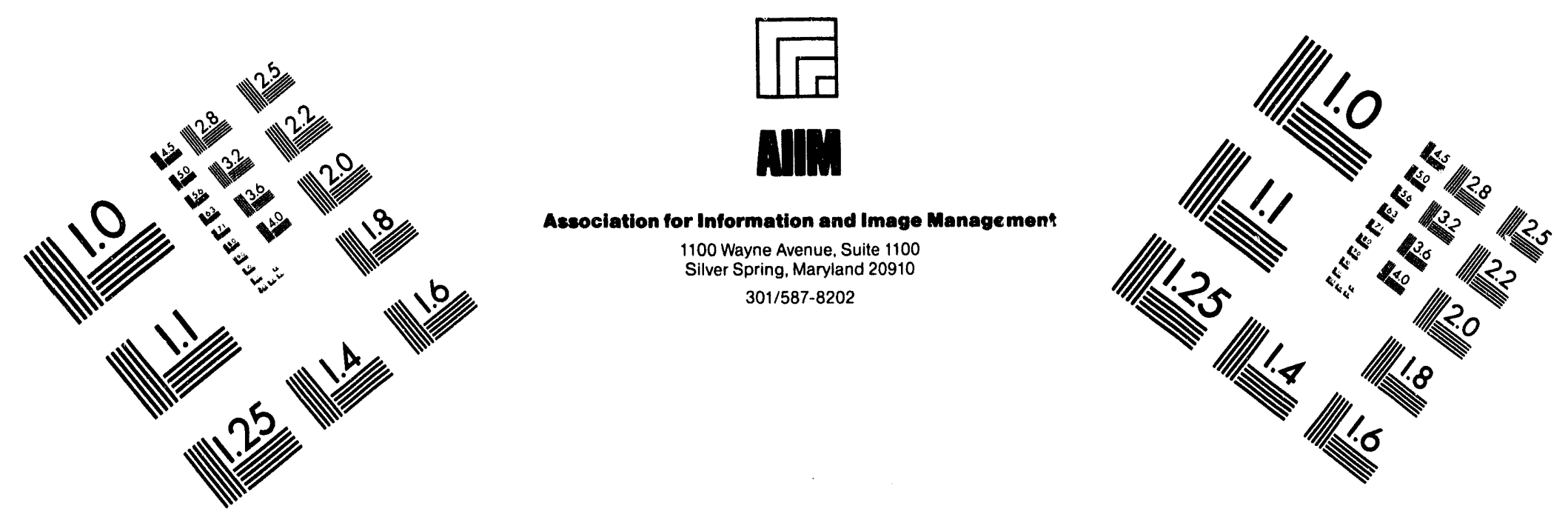

\title{
Centimeter
}

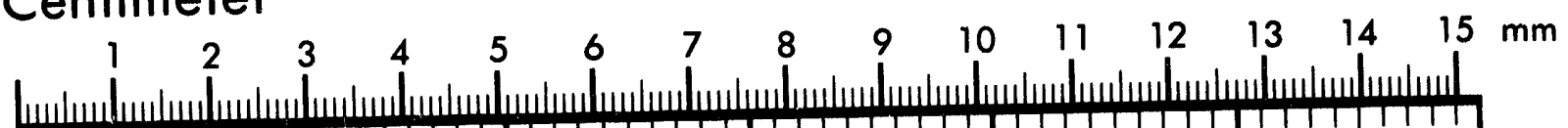

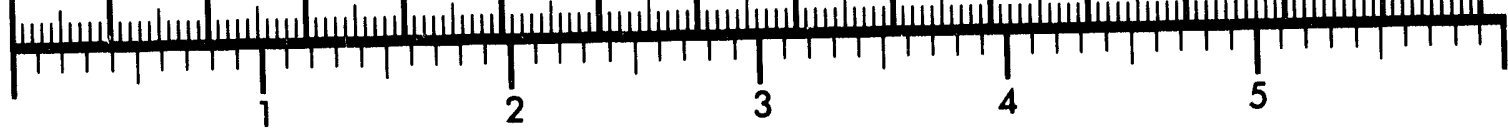
Inches
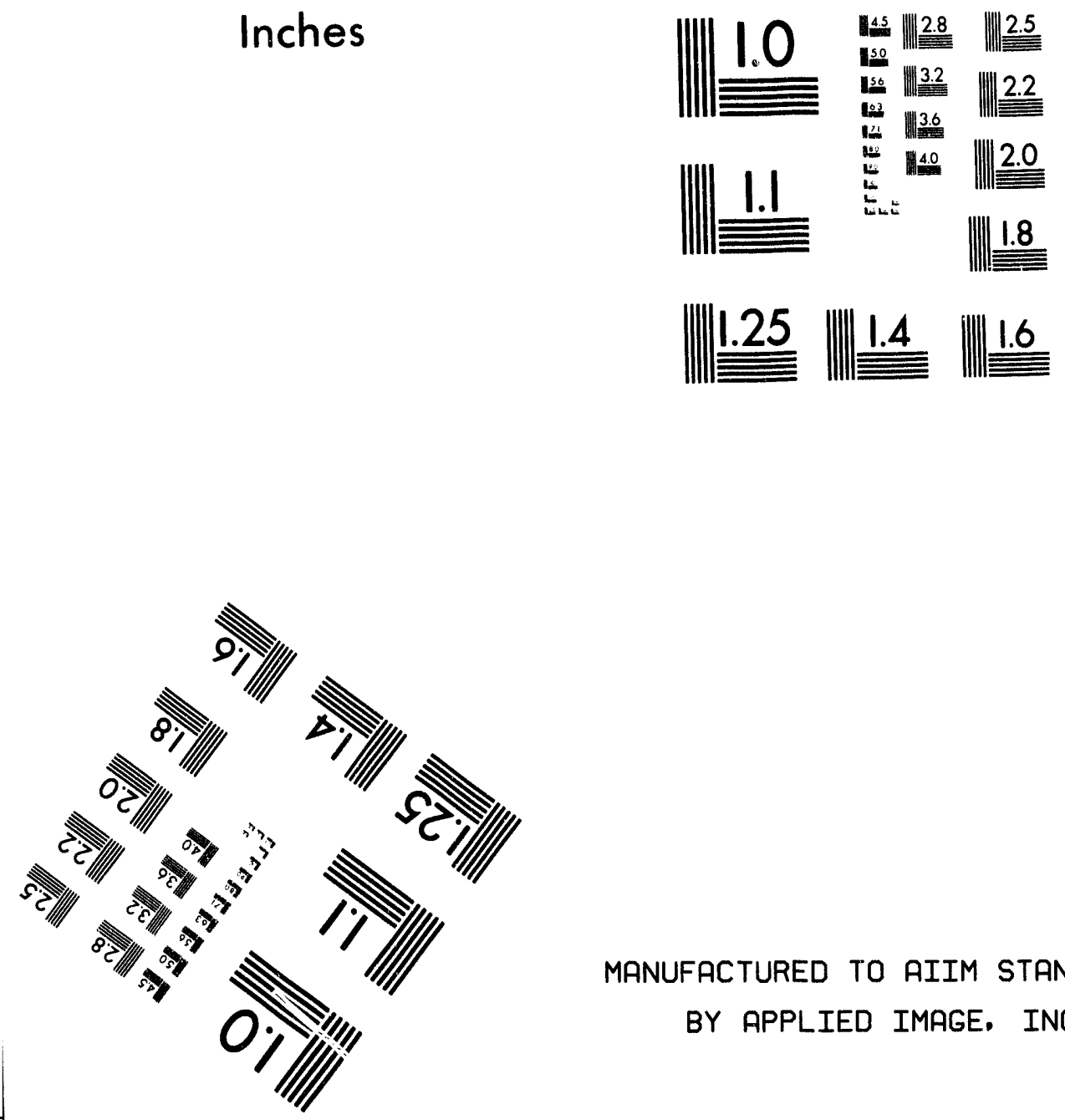

MANUFACTURED TO AIIM STANDARDS

$$
\text { BY APPLIED IMAGE, INC. }
$$

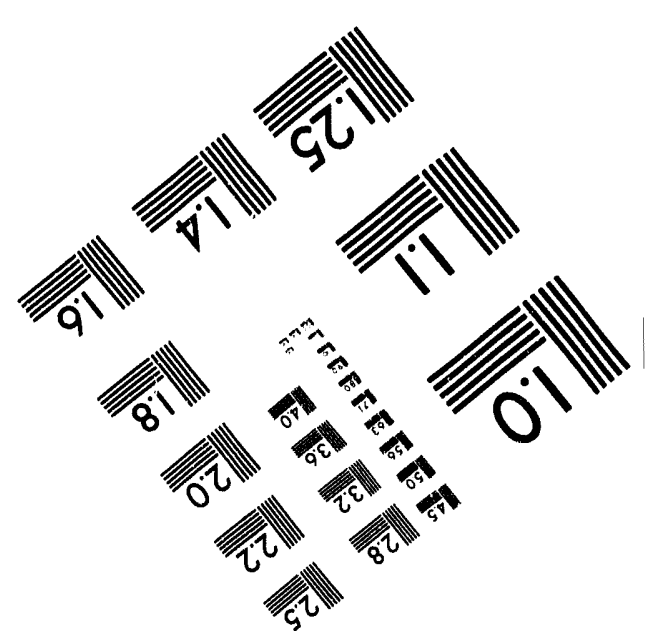



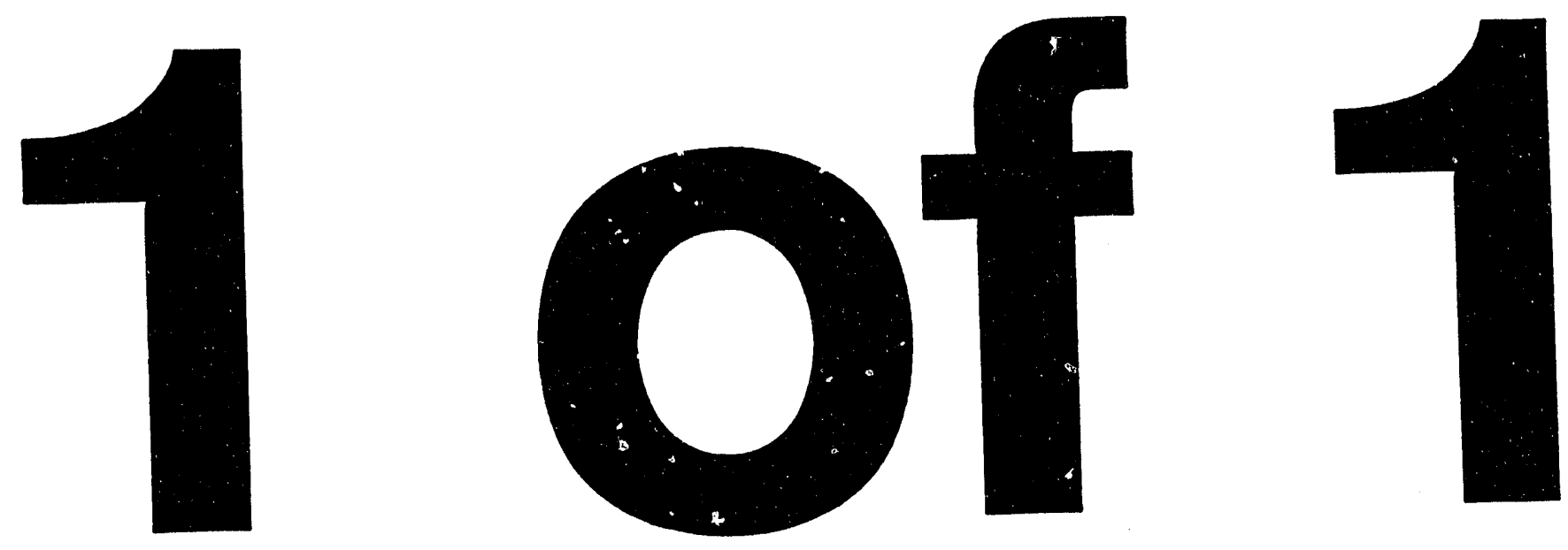
DOE/NASA/26310-19

NASA TM-106319

\section{Effects of Thermomechanical Processing on Tensile and Long-Time Creep Behavior of Nb-1\%Zr-0.1\%C Sheet}

Robert H. Titran

National Aeronautics and Space Administration

Lewis Research Center

Cleveland, Ohio 44135

and

Mehmet Uz

Lafayette College

Easton, Pennsylvania 18042

Work performed for

U.S. DEPARTMENT OF ENERGY

Nuclear Energy

Reactor Systems Development and Technology

Washington, D.C. 20545

Under Interagency Agreement DE-Al03-86SF16310

Prepared for

The Metallurgical Society Annual Meeting

San Francisco, California, February 27-March 3, 1994 


\title{
EFFECTS OF THERMOMECHANICAL PROCESSING ON TENSILE AND
}

\section{LONG-TIME CREEP BEHAVIOR OF Nb-1\%Zr-0.1\%C SHEET}

\author{
Robert H. Titran \\ National Aeronautics and Space Administration \\ Lewis Research Center \\ Cleveland, Ohio 44135 \\ and \\ Mehmet Uz \\ Lafayette College \\ Easton, Pennsylvania 18042
}

\begin{abstract}
SUMMARY
Effects of thermomechanical processing on the mechanical properties of $\mathrm{Nb}-1 \mathrm{wt} . \% \mathrm{Zr}-0.1 \mathrm{wt} . \% \mathrm{C}$, a candidate alloy for use in advanced space power systems, were investigated. Sheet bars were cold rolled into $1-\mathrm{mm}$ thick sheets following single, double, or triple extrusion operations at $1900 \mathrm{~K}$. All the creep and tensile specimens were given a two-step heat treatment of $1 \mathrm{hr}$ at $1755 \mathrm{~K}+2 \mathrm{hr}$ at $1475 \mathrm{~K}$ prior to testing. Tensile properties were determined at 300 as well as at $1350 \mathrm{~K}$. Microhardness measurements were made on cold rolled, heat treated, and crept samples. Creep tests were carried out at $1350 \mathrm{~K}$ and 34.5 MPa for times of about 10,000 to $19,000 \mathrm{hr}$. The results show that the number of extrusions had some effects on both the microhardness and tensile properties. However, the long-time creep behavior of the samples were comparable, and all were found to have adequate properties to meet the design requirements of advanced power systems regardless of thermomechanical history. The results are discussed in correlation with processing and microstructure, and further compared to the results obtained from the testing of $\mathrm{Nb}-1 \mathrm{wt} . \% \mathrm{Zr}$ and $\mathrm{Nb}-1 \mathrm{wt} . \% \mathrm{Zr}-0.06 \mathrm{wt} . \% \mathrm{C}$ alloys.
\end{abstract}

\section{INTRODUCTION AND BACKGROUND}

Space power systems are expected to produce electrical power ranging from hundreds of kilowatts to several megawatts. To provide such high levels of power, advanced nuclear power systems currently appear to be the only feasible choice. It is critical to select the appropriate materials to meet the design requirements for such an advanced power system. These requirements currently include a service life of 7 years or more under stresses of 5 to $25 \mathrm{MPa}$ at 1350 to $1450 \mathrm{~K}$ in an environment of a liquid alkali metal such as lithium, and total allowable strain of 2 percent maximum (refs. 1 and 2 ).

Refractory metals and their alloys are the leading candidates for high-temperature applications due to their high melting points. In particular, various alloys of niobium $(\mathrm{Nb}$, melting point $=2742 \mathrm{~K})$ with zirconium ( $\mathrm{Zr}$ ) and/or carbon (C) have been selected for use in advanced space power systems (ref. 1). This choice was based primarily on the resistance of $\mathrm{Nb}$ and its alloys to liquid alkali metal corrosion and their lower densities as compared to the other refractory metals and alloys. Initially, solid-solution strengthened $\mathrm{Nb}-1 \mathrm{Zr}$ alloy (this and all the compositions that follow in this paper are expressed in wt.\%) was chosen for use in space power conversion systems with a service temperature of about $1000 \mathrm{~K}$ and a maximum stress of around $10 \mathrm{MPa}$ (refs. 3 and 4). However, this alloy was not developed for appli- 
cations requiring long-time stability at temperatures over $1100 \mathrm{~K}$ or those with higher stress levels. Because the design requirements of the advanced power systems are currently more stringent involving higher stresses at higher temperatures for longer times, long-term creep resistance of a material becomes the primary concern.

In earlier studies (refs. 5 and 6), a double-annealed (DA: $1 \mathrm{hr}$ at $1755 \mathrm{~K}+2 \mathrm{hr}$ at $1475 \mathrm{~K}$ both steps followed by furnace cooling) $\mathrm{Nb}-1 \mathrm{Zr}-0.06 \mathrm{C}$ alloy was reported to have about five times the creep strength of a similarly heat-treated $\mathrm{Nb}-1 \mathrm{Zr}$ alloy at $1350 \mathrm{~K}$ and $10 \mathrm{MPA}$. Under these conditions, the alloy containing $0.06 \mathrm{wt} . \%$ carbon had no measurable creep strain after $34,500 \mathrm{hr}$. However, the $\mathrm{Nb}-1 \mathrm{Zr}$ alloy achieved 2 percent strain in nearly $18,000 \mathrm{hr}$, and it had a total creep strain of more than 4 percent after about $31,000 \mathrm{hr}$ of testing. The $\mathrm{Nb}-1 \mathrm{Zr}$ alloy containing carbon owes its superior creep resistance to the presence of extremely stable cubic carbides of $\mathrm{Zr}$ and $\mathrm{Nb}$ (refs. 7 and 8 ). These earlier studies clearly show that the carbide-strengthened $\mathrm{Nb}-1 \mathrm{Zr}$ alloy has much better creep resistance than the solid solutionstrengthened $\mathrm{Nb}-1 \mathrm{Zr}$.

The current investigation was undertaken as part of a larger project assessing the feasibility of using $\mathrm{Nb}-1 \mathrm{Zr}-\mathrm{C}$ alloys in advanced power system applications. In particular, this paper deals with the effects of thermomechanical processing history on the microhardness, tensile, and creep properties of a $\mathrm{Nb}-1 \mathrm{Zr}-0.1 \mathrm{C}$ alloy, which is also known as PWC-11 (ref. 9). Also included are the tensile and/or creep properties of $\mathrm{Nb}-1 \mathrm{Zr}$ and $\mathrm{Nb}-1 \mathrm{Zr}-0.06 \mathrm{C}$ alloys in order to assess the effects of the carbon-content on these properties.

\section{EXPERIMENTAL}

\section{Materials and Apparatuses}

The nominal compositions of the materials evaluated in this study are given in table $\mathrm{I}$. All the samples were in sheet form with a thickness of about $1 \mathrm{~mm}$. The condition in which each specimen was tested and/or examined can be seen from table II. The $\mathrm{Nb}-1 \mathrm{Zr}$ and $\mathrm{Nb}-1 \mathrm{Zr}-0.06 \mathrm{C}$ samples are included for comparison purposes, and detailed information about these samples can be found in earlier work reported (refs. 6 to 8 and 10 ).

The designation of the samples will be as given in tables I and II in the remainder of this manuscript. The $\mathrm{Nb}-1 \mathrm{Zr}$ samples are designated as such, those containing $0.1 \mathrm{C}$ are labeled with the heat number (054-), and the samples containing $0.06 \mathrm{C}$ are labeled LC- (lower carbon as compared to 064 samples). Each alphanumeric identification is followed by extension(s) descriptive of processing and/or testing. The label of each creep-tested sample contains a number giving the test stress in megapascals following the process indicator. It should be noted that the temperature of the creep tests at 10 and $34.5 \mathrm{MPa}$ was 1350 $\mathrm{K}$, and that of the tests at $24 \mathrm{MPa}$ was $1450 \mathrm{~K}$. Then, for example the sample designated LC-DA10 would be a double-annealed $\mathrm{Nb}-1 \mathrm{Zr}-0.06 \mathrm{C}$ sample creep tested at $1350 \mathrm{~K}$ and $10 \mathrm{MPa}$ for the time indicated in table II.

The $\mathrm{Nb}-1 \mathrm{Zr}-0.1 \mathrm{C}$ samples were all fabricated from a vacuum arc-melted ingot by a combination of hot extrusion and cold rolling. The extrusion operations were performed at $1900 \mathrm{~K}$ with an extrusion ratio of $4: 1$. The primary difference between $064 \mathrm{~A}, 064 \mathrm{~B}$, and $064 \mathrm{C}$ in table II was that they were, respectively, single-, double-, and triple-extruded prior to cold rolling.

An internally-loaded, constant-load, ultrahigh vacuum chamber was used for the creep tests. It was equipped with split-sleeve resistance heaters (ref. 11) and a viewing port to facilitate observation of 
TABLE I.-CHEMICAL COMPOSITIONS OF DOUBLEANNEALED (DA: 1 HR AT $1755 \mathrm{~K}+2$ HR

AT $1475 \mathrm{~K}) \mathrm{Nb}-1 \mathrm{Zr}$ AND

$\mathrm{Nb}-1 \mathrm{Zr}-\mathrm{C}$ ALLOYS

\begin{tabular}{|l|r|r|r|r|c|}
\hline \multirow{2}{*}{ Sample } & \multicolumn{5}{|c|}{ Chemical composition, } \\
& \multicolumn{1}{|c|}{$0^{\mathrm{a}}$} & \multicolumn{1}{|c|}{$\mathrm{N}^{\mathrm{a}}$} & $\mathrm{C}^{\mathrm{b}}$ & $\mathrm{Z} \mathrm{r}^{\mathrm{c}}$ & $\mathrm{Nb}$ \\
\cline { 2 - 6 } & & \multicolumn{1}{|c|}{$\mathrm{Nb}$} & \\
\hline $\mathrm{Nb}-1 \mathrm{Zr}$ & 0.0170 & 0.0041 & 0.0016 & 1.1 & Balance \\
LC-DA & .0080 & .0053 & .0630 & .90 & $\downarrow$ \\
064A-DA & .0028 & .0019 & .0921 & .95 & \\
064B-DA & .0033 & .0022 & .0914 & .95 & $\downarrow$ \\
064C-DA & .0022 & .0009 & .0944 & .95 & $\downarrow$ \\
\hline
\end{tabular}

anert-gas fusion method.

${ }^{b}$ Combustion extraction method.

Inductively-coupled plasma method.

TABLE II.-PROCESSING HISTORIES OF Nb-1Zr, Nb-1Zr-0.06C, AND Nb-1Zr-0.1C SHEET SAMPLES

\begin{tabular}{|c|c|c|}
\hline Sample & $\begin{array}{l}\text { Number of } \\
\text { extrusions }^{\mathrm{a}}\end{array}$ & Heat treatment/condition \\
\hline $\begin{array}{l}\mathrm{Nb}-1 \mathrm{Zr}-\mathrm{A} \\
\mathrm{Nb}-1 \mathrm{Zr}-\mathrm{A} 34\end{array}$ & - & $\begin{array}{l}1 \mathrm{hr} \text { at } 1475 \mathrm{~K} \\
1 \mathrm{hr} \text { at } 1475 \mathrm{~K}+218 \mathrm{hr} \text { at } 1350 \mathrm{~K} \text { and } 34.5 \mathrm{MPa}\end{array}$ \\
\hline $\begin{array}{l}\text { Nb-1Zr-DA } \\
\text { Nb-1Zr-DA10 }\end{array}$ & - & $\begin{array}{l}\text { DOUBLE-ANNEALED, } \text { DA }^{d} \\
\text { DA }+31780 \mathrm{hr} \text { at } 1350 \mathrm{~K} \text { and } 10 \mathrm{MPa}\end{array}$ \\
\hline $\begin{array}{l}\text { LC-DA } \\
\text { LC-DA10 } \\
\text { LC-DA34 }\end{array}$ & - & $\begin{array}{l}\text { DOUBLE-ANNEALED, DA } \\
\mathrm{DA}+34500 \mathrm{hr} \text { at } 1350 \mathrm{~K} \text { and } 10 \mathrm{MPa} \\
\mathrm{DA}+4288 \mathrm{hr} \text { at } 1350 \mathrm{~K} \text { and } 34.5 \mathrm{MPa}\end{array}$ \\
\hline $\begin{array}{l}\text { LC-DA/AGE } \\
\text { LC-DA/AGE10 }\end{array}$ & - & $\begin{array}{l}\text { DOUBLE-ANNEALED, DA, + AGEDe } \\
\mathrm{DA}+\mathrm{AGE}+32500 \mathrm{hr} \text { at } 1350 \mathrm{~K} \text { and } 10 \mathrm{MPa}\end{array}$ \\
\hline $\begin{array}{l}\text { 064A } \\
\text { 064A-DA } \\
\text { 064A-DA34(E) } \\
\text { 064A-DA34(M) }\end{array}$ & $\begin{array}{l}1 \\
1 \\
1 \\
1\end{array}$ & $\begin{array}{l}\text { AS COLD ROLLED }(96 \% \mathrm{CW}) \\
\text { DOUBLE-ANNEALED, DA } \\
\text { DA }+18780 \mathrm{hr} \text { at } 1350 \mathrm{~K} \\
\mathrm{DA}+18780 \mathrm{hr} \text { at } 1350 \mathrm{~K} \text { and } 34.5 \mathrm{MPa}\end{array}$ \\
\hline $\begin{array}{l}\text { O64B } \\
\text { 064B-DA } \\
\text { 064B-DA34(E) } \\
\text { 064B-DA34(M) }\end{array}$ & $\begin{array}{l}2 \\
2 \\
2 \\
2\end{array}$ & $\begin{array}{l}\text { AS COLD ROLLED }(88 \% \mathrm{CW}) \\
\text { DOUBLE-ANNEALED, DA } \\
\text { DA }+15460 \mathrm{hr} \text { at } 1350 \mathrm{~K} \\
\text { DA }+15460 \mathrm{hr} \text { at } 1350 \mathrm{~K} \text { and } 34.5 \mathrm{MPa}\end{array}$ \\
\hline $\begin{array}{l}\text { 064C } \\
\text { 064C-DA } \\
\text { 064C-DA34(E) } \\
\text { 064C-DA34(M) }\end{array}$ & $\begin{array}{l}3 \\
3 \\
3 \\
3\end{array}$ & $\begin{array}{l}\text { AS COLD ROLLED }(60 \% \mathrm{CW}) \\
\text { DOUBLE-ANNEALED, DA } \\
\mathrm{DA}+9950 \mathrm{hr} \text { at } 1350 \mathrm{~K} \\
\mathrm{DA}+9950 \mathrm{hr} \text { at } 1350 \mathrm{~K} \text { and } 34.5 \mathrm{MPa}\end{array}$ \\
\hline
\end{tabular}

aNumber of hot extrusions employed in fabricating sheet bars prior to cold rolling.

$\mathrm{b}(\mathrm{E})$ : Stress-free end portions of crept sample.

${ }^{c}(M)$ : Stressed middle portion of crept sample.

dDA: A 2-step anneal of $1 \mathrm{hr}$ at $1755 \mathrm{~K}+2 \mathrm{hr}$ at $1475 \mathrm{~K}$.

eAGE: A heat treatment of $1000 \mathrm{hr}$ at $1350 \mathrm{~K}$. 
the sample. Ultrahigh vacuum chambers were also used for all the heat treatments. The pressure in these high-temperature chambers during testing was of the order of $10^{-6} \mathrm{~Pa}$. A screw-driven tensile testing machine was used for both the room and high-temperature tensile tests. The temperature in a chamber during high-temperature tests was measured using an R-type (Pt/Pt-13\% Rh) thermocouple. The temperature in the chambers was maintained within $\pm 5^{\circ}$ of the intended test temperature. A microhardness tester equipped with a diamond pyramid indentor and a digital processor/printer was used for the hardness measurements.

\section{Procedure}

All the testing and evaluation in this study were conducted on longitudinal samples, i.e., the direction of applied load in tensile and creep tests and the surfaces examined were parallel to the rolling direction of the sheet. Prior to testing and annealing, the samples were chemically cleaned using a solution of $\mathrm{H}_{2} \mathrm{O}: \mathrm{HNO}_{3}: \mathrm{HF}$ with a volume ratio of 3:1:1. Furthermore, to avoid interstitial impurity contamination during exposure to elevated temperatures, the samples were wrapped in chemically-cleaned tantalum foil prior to heat treating and high-temperature testing.

The creep and tensile test specimens were similar in geometry. The sketch of a typical sample showing dimensions is shown in figure 1. Fiducial marks were placed in the narrow gage section of each sample to facilitate the measurement or monitoring of the changes in sample length.

One sample from each of the 064A-DA, 064B-DA, and 064C-DA (see table II) was creep tested uniaxially at $1350 \mathrm{~K}$ under a stress of about $34.5 \mathrm{MPa}$. The test was carried out for a period of $18,780 \mathrm{hr}$ for 064A-DA, 15,460 hr for 064B-DA, and $9950 \mathrm{hr}$ for 064C-DA. The times and conditions of the creep tests on the samples from the $\mathrm{Nb}-1 \mathrm{Zr}$ and $\mathrm{Nb}-1 \mathrm{Zr}-0.06 \mathrm{C}$ alloys were as given in table $\mathrm{I}$. The elongation, i.e., the change in the distance between the fiducial marks, was measured optically through the holes punched in the tantalum wrap using a cathetometer.

Tensile tests on samples from each of 064A-DA, 064B-DA, and 064C-DA were made in duplicate at 300 and $1350 \mathrm{~K}$. The cross-head speed during these tests was about $21.17 \times 10^{-6} \mathrm{~m} / \mathrm{s}$ which corresponds to a strain rate of about $8 \times 10^{-4} \mathrm{~s}^{-1}$ assuming that the deformation was restricted to the $25-\mathrm{mm}$ gage section of the sample. The tensile properties of ultimate tensile strength (UTS), 0.2 percent offset yield strength (YS), ductility $(\varepsilon)$, and uniform elongation $\left(\varepsilon_{u}\right)$ were determined from a load-time plot obtained for each test using the widely-known equations and conventional methods (ref. 12).

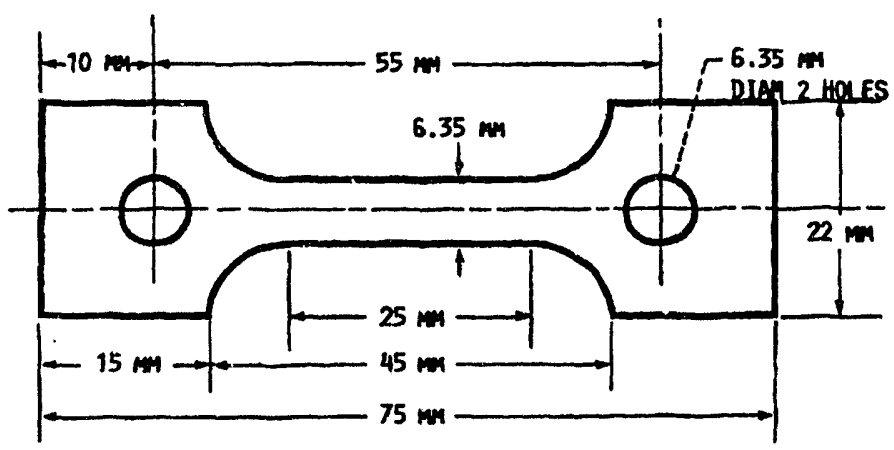

Figure 1.-A schematic of the specimens used in tensile and creep tests. 
Vickers hardness measurements were made on all of the 064-samples listed in table II. The number of readings varied from 6 to 20 per sample depending on the sample surface available.

Optical micrographs of the 064-samples were taken in the as-polished condition before and after creep testing to correlate the mechanical properties to microstructure and processing.

\section{RESULTS AND DISCUSSION}

\section{Microstructure}

The microstructures of the $\mathrm{Nb}-1 \mathrm{Zr}$ and $\mathrm{Nb}-1 \mathrm{Zr}-0.06 \mathrm{C}$ alloys as well as the effects of thermomechanical processing and various heat treatments on the microstructure of $\mathrm{Nb}-1 \mathrm{Zr}-0.1 \mathrm{C}$ sheets $(064-$ samples in table II) were discussed in earlier publications (refs. 5 to 8 and 13). Hence, they will be discussed here as they are pertinent to the present study with the emphasis on the double-annealed and ascrept microstructures of the samples from 064A, 064B, and 064C.

Prior to heat treating, all the samples had typical cold-rolled microstructures with grains elongated and the precipitates aligned along the rolling direction. In the samples containing carbon, the precipitates were mainly orthorhombic $\mathrm{Nb}_{2} \mathrm{C}$ with some fine cubic carbides of $\mathrm{Zr}$ and $\mathrm{Nb}$ (refs. 8 and 13). The only precipitates found in the $\mathrm{Nb}-1 \mathrm{Zr}$ samples were fine $\mathrm{ZrO}_{2}$ (ref. 5).

The samples from the $\mathrm{Nb}-1 \mathrm{Zr}$ alloy were either given a heat treatment of $1 \mathrm{hr}$ at $1475 \mathrm{~K}$ (sample $\mathrm{Nb}-1 \mathrm{Zr}-\mathrm{A}$ in table II) or they were double-annealed, $1 \mathrm{hr}$ at $1755 \mathrm{~K}+2 \mathrm{hr}$ at $1475 \mathrm{~K}(\mathrm{Nb}-1 \mathrm{Zr}-\mathrm{DA}$ in table II) before being creep tested. Both heat treatments resulted in a recrystallized microstructure with some dispersion of fine $\mathrm{ZrO}_{2}$ particles throughout the matrix (ref. 5).

The microstructures of the samples from the $\mathrm{Nb}-1 \mathrm{Zr}-0.1 \mathrm{C}$ sheets before and after creep testing at $1350 \mathrm{~K}$ and $34.5 \mathrm{MPa}$ are shown in figure 2. An examination of the micrographs in (a) to (c) shows that the effects of the number of extrusions on the double-annealed microstructures were quite noticeable. The sample from the single-extruded sheet, 064A-DA, had a fully recrystallized microstructure with relatively large grains and rather coarse precipitates along the grain boundaries and within the grains alike. Sample 064B-DA was also recrystallized with a microstructure similar to 064A-DA, but with smaller grains. The double-annealed sample from the triple-extruded sheet, 064C-DA, had a microstructure with highly-elongated grains giving no indication of full recrystallization. The precipitates in 064A-DA were primarily orthorhombic $\mathrm{Nb}_{2} \mathrm{C}$ with some cubic $(\mathrm{Zr}, \mathrm{Nb}) \mathrm{C}$. The relative amount of the more stable cubic carbides of $(\mathrm{Zr}, \mathrm{Nb}) \mathrm{C}$ increased with the number of extrusions in both the as-rolled and double-annealed samples (ref. 13).

The micrographs in figures 2(d) to (f) show the microstructures of the stressed middle portions of the crept samples. The microstructure of the stress-free end of each sample was similar to that of its middle. There does not appear to be any discernable difference between the microstructures of the crept samples 064A-DA34, 064B-DA34, and 064C-DA34. It is evident, however, that prolonged exposure to $1350 \mathrm{~K}$ gave rise to significant changes in the double-annealed microstructure of each sample. Such exposure caused the rather coarse $\mathrm{Nb}_{2} \mathrm{C}$, which was the primary carbide in the double-annealed samples, to transform to the finer and more stable $(\mathrm{Zr}, \mathrm{Nb}) \mathrm{C}$ finely distributed throughout the matrix in all the crept samples regardless of the processing history. The double-annealed and as-crept microstructures of the samples from the $\mathrm{Nb}-1 \mathrm{Zr}-0.06 \mathrm{C}$ sheet (LC-DA34) were similar to those of 064A-DA34 shown in figure 2. However, the microstructure of LC-DA34 had smaller grains and less amount of precipitates throughout its matrix (refs. 5, 7, and 8). 

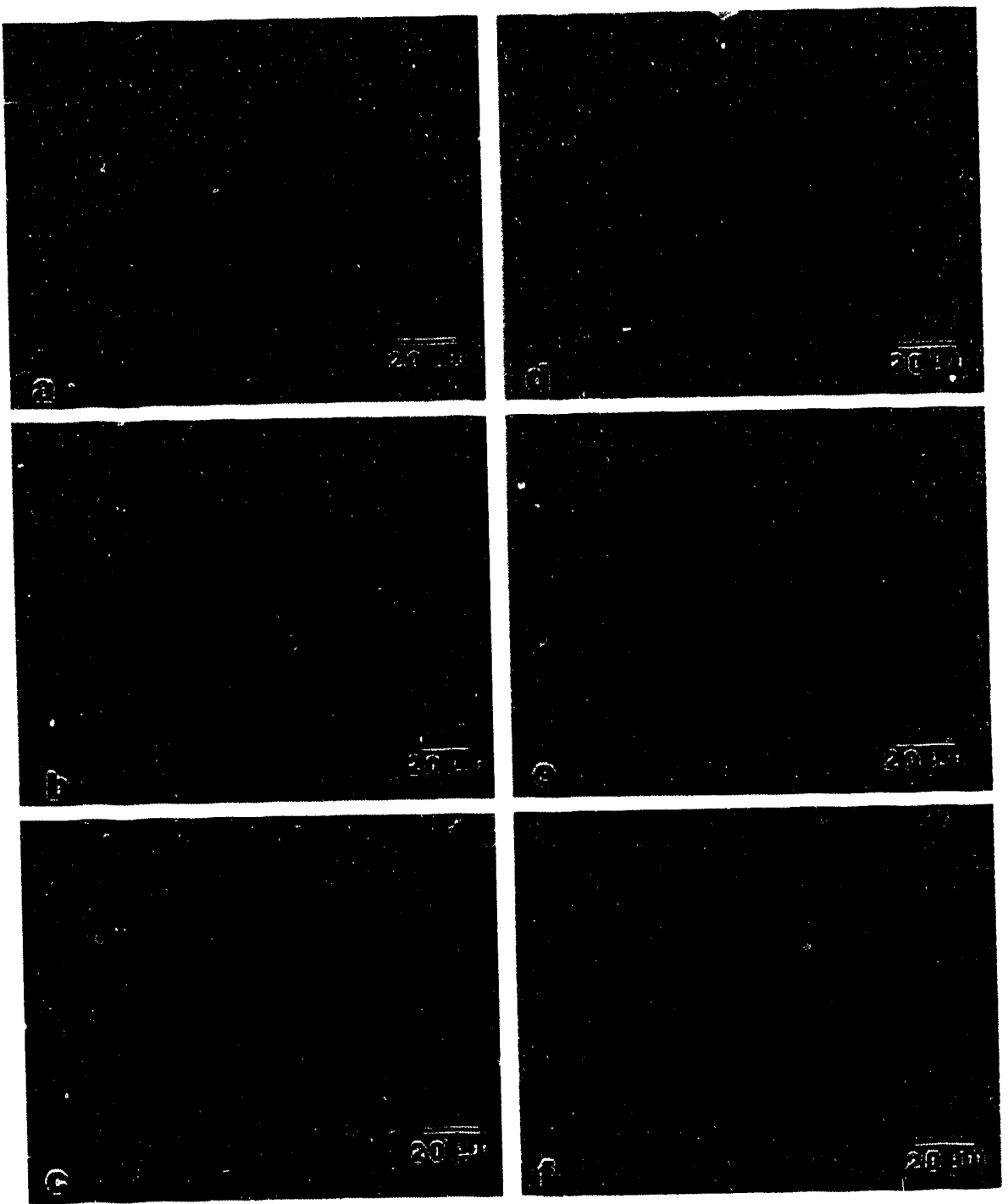

Figure 2.-Optical micrographs of the Nb-1Zr-0.1C samples before and after creep testing at $1350 \mathrm{~K}$ and $34.5 \mathrm{MPa}$. All differential interference contrast (DIC) images of as-polished samples, and the longitudinal or rolling direction is parallel to the lines of text. (a) 064A-DA. (b) 064B-DA. (c) 064C-DA. (d) 064A-DA34(M). (e) 064B-DA34(M). (f) 064C-DA34(M).

\section{Microhardness}

Microhardness measurements were made on the samples from the $\mathrm{Nb}-1 \mathrm{Zr}-0.1 \mathrm{C}$ sheets in the asrolled and double-annealed conditions as well as on their stressed middle and stress-free end portions following creep testing. The results are tabulated in table III and are also plotted as bar graphs in figure 3 to facilitate better visualization of the differences. The results show that in a given condition, the microhardness of the specimens from the single-, double-, and triple-extruded sheets fall within about one standard deviation of one another. This would indicate that the number of extrusions prior to cold rolling did not have a significant effect on the microhardness of these samples regardless of the condition. As expected, double-anneal resulted in a marked decrease of about 40 percent in the microhardness of each sample. This is attributable to the relief of internal stresses and the effects of cold work by recovery and recrystallization during such heat treatment. Also expected was that the stressed middle of each sample 
TABLE III.-MICROHARDNESS OF Nb-1Zr-0.1C SHEET SAMPLES DESCRIBED IN TABLE II

\begin{tabular}{|l|c|c|}
\hline \multicolumn{1}{|c|}{ Sample } & $\begin{array}{c}\text { Vickers hardness } \\
\text { number, } \\
\text { VHN }\end{array}$ & $\begin{array}{c}\text { Standard } \\
\text { deviation, } \\
\mp \mathrm{S}_{\mathrm{n}}\end{array}$ \\
\hline 064A & 179.1 & 5.8 \\
064A-DA & 104.0 & 4.0 \\
064A-DA34(E) & 90.3 & 4.6 \\
064A-DA34(M) & 112.2 & 10.1 \\
O64B & 163.0 & 10.0 \\
064B-DA & 95.5 & 9.1 \\
064B-DA34(E) & 101.9 & 10.7 \\
064B-DA34(M) & 128.3 & 3.8 \\
064C & 157.5 & 6.5 \\
064C-DA & 104.0 & 5.2 \\
064C-DA34(E) & 100.4 & 5.4 \\
064C-DA34(M) & 112.9 & 4.3 \\
\hline
\end{tabular}

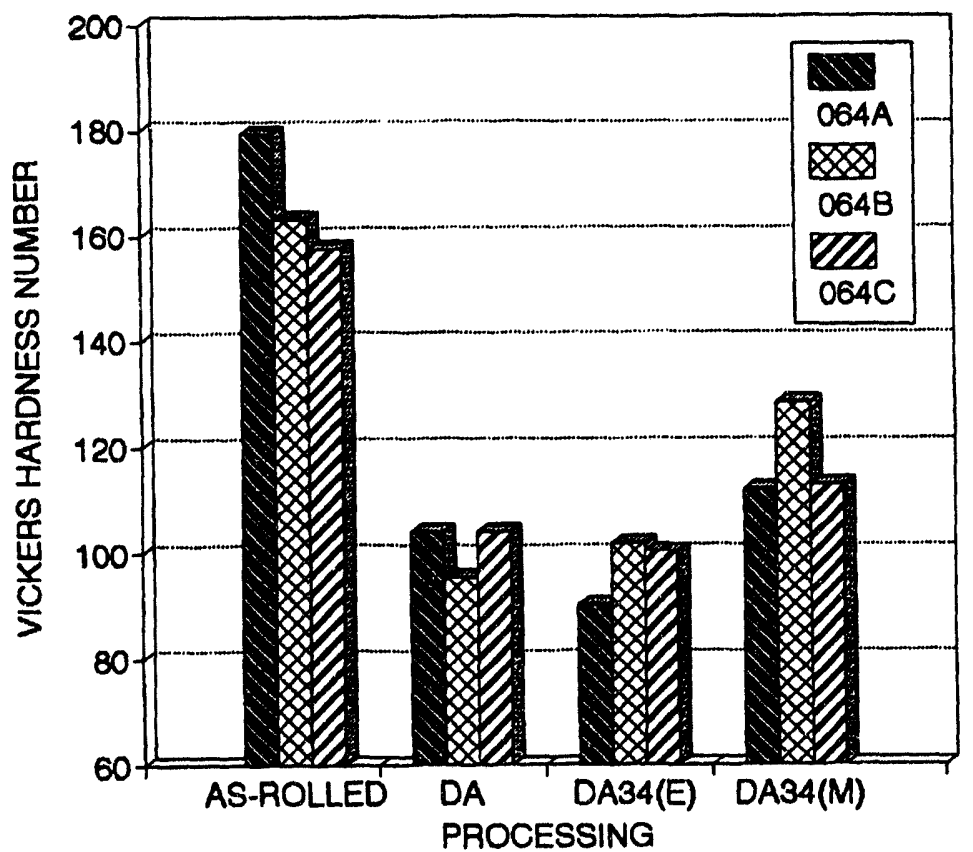

Figure 3.-Bar graphs of the microhardness of samples from as-rolled, as double-annealed and as-crept $\mathrm{Nb}-1 \mathrm{Zr}-0.1 \mathrm{C}$ specimens.

had a slightly higher microhardness than its stress-free ends. This should be due to the strain induced in the reduced gage section of the crept sample even though the total creep strain in each was extremely small as will be discussed shortly. It is very interesting to note from the results that prolonged exposure to $1350 \mathrm{~K}$ for approximately 10,000 to $19,000 \mathrm{hr}$ had no measurable effect on the microhardness of the double-annealed samples. This can be attributed to the predominant presence of the extremely stable and finely-distributed cubic carbides of $(\mathrm{Zr}, \mathrm{Nb}) \mathrm{C}$ in the crept samples. 


\section{Tensile Properties}

The results of the tensile tests at 300 and $1350 \mathrm{~K}$ are tabulated in table IV. The difference between the duplicate values was less than 5 percent relative to the averages reported in the table. Ultimate tensile strength, yield strength, and ductility data are also presented in bar-graph form in figures 4 to 6 , respectively.

The tensile strengths of 064A-DA, 064B-DA, and 064C-DA were comparable to one another with 064C-DA being a little higher than the other two at both 300 and $1350 \mathrm{~K}$ (see table IV and fig. 4). This indicates that multiple extrusions did not have a significant effect on the tensile strength either as was the case for the microhardness of these samples presented above. Slightly higher tensile strength of 064C-DA should be expected because this sample had an oriented microstructure with grains elongated in the load (longitudinal) direction. The tensile strengt: of the solid-solution strengthened $\mathrm{Nb}-1 \mathrm{Zr}-\mathrm{A}$ was lower than all of the precipitation-strengthened 064-sheets at $300 \mathrm{~K}$, but they were comparable to one another at $1350 \mathrm{~K}$.

The trends concerning yield strengths (see table IV and fig. 5) were different than those observed for the tensile strength. The yield strengths of 064A-DA and 064B-DA were comparable to one another, but both were measurably lower than $064 \mathrm{C}-\mathrm{DA}$ at $300 \mathrm{~K}$ as well as at $1350 \mathrm{~K}$. The yield strength of Nb$1 \mathrm{Zr}-\mathrm{A}$ was close to that of 064C-DA at $300 \mathrm{~K}$, and it was lower than all of the 064-samples at $1350 \mathrm{~K}$.

The ductility data in table IV and figure 6 show that the values for 064A-DA and 064B-DA were both about 35 percent at $300 \mathrm{~K}$ and increased to about 40 percent at $1350 \mathrm{~K}$. The ductility of 064C-DA was lower, and that of $\mathrm{Nb}-1 \mathrm{Zr}-\mathrm{A}$ was higher than either (of 064A-DA and 064B-DA) at both temperatures. Rather unexpected was that the ductility of $\mathrm{Nb}-1 \mathrm{Zr}-\mathrm{A}$ as well as of 064C-DA was considerably lower at $1350 \mathrm{~K}$ than at $300 \mathrm{~K}$.

It is evident from the above results that each of the samples tested has tensile properties which are more than adequate for the advanced power system applications considering the maximum service stress of about $25 \mathrm{MPa}$. None of these materials should have brittle failure, nor should they have any strengthrelated problems during operation.

TABLE IV.-RESULTS OF TENSILE TESTS ON SAMPLES FROM Nb-1Zr AND Nb-1Zr-0.1C SHEETS AT 300 AND $1350 \mathrm{~K}$.

\begin{tabular}{|c|c|c|c|c|c|c|}
\hline \multirow[t]{2}{*}{ Sample } & \multicolumn{2}{|c|}{ Test conditions } & \multicolumn{4}{|c|}{ Test results } \\
\hline & $\begin{array}{c}\text { Temperature, } \\
\text { K }\end{array}$ & $\underset{1 / \sec ^{b}}{\varepsilon \times 10^{4}}$ & $\begin{array}{l}\text { UTS, } \\
\text { MPa }\end{array}$ & $\begin{array}{c}0.2 \% \mathrm{YS}, \\
\mathrm{MPa}\end{array}$ & $\begin{array}{l}\varepsilon \\
\%^{b}\end{array}$ & $\begin{array}{l}\varepsilon_{u} \\
\%_{b}^{b}\end{array}$ \\
\hline \multirow[t]{2}{*}{$\mathrm{Nb}-1 \mathrm{Zr}-\mathrm{A}^{\mathrm{a}}$} & 300 & 4 & 224 & 127 & 41 & 26 \\
\hline & 1350 & 4 & 126 & 76 & 33 & 18 \\
\hline \multirow[t]{2}{*}{ 064A-DA } & 300 & 8.33 & 263.9 & 108.1 & 35.8 & 24.8 \\
\hline & 1350 & 8.33 & 126.3 & 88.1 & 42.1 & 14.9 \\
\hline \multirow[t]{2}{*}{ 064B-DA } & 300 & 8.33 & 257.3 & 105.4 & 35.2 & 24.4 \\
\hline & 1350 & 8.33 & 115.9 & 84.1 & 39.6 & 13.1 \\
\hline \multirow[t]{2}{*}{ 064C-DA } & 300 & 8.33 & 281.0 & 134.2 & 28.1 & 19.8 \\
\hline & 1350 & 8.33 & 134.9 & 113.1 & 24.0 & 5.3 \\
\hline
\end{tabular}

aFrom reference 10 .

based on the assumption that the elongation was restricted to $25-\mathrm{mm}$ gage region. 


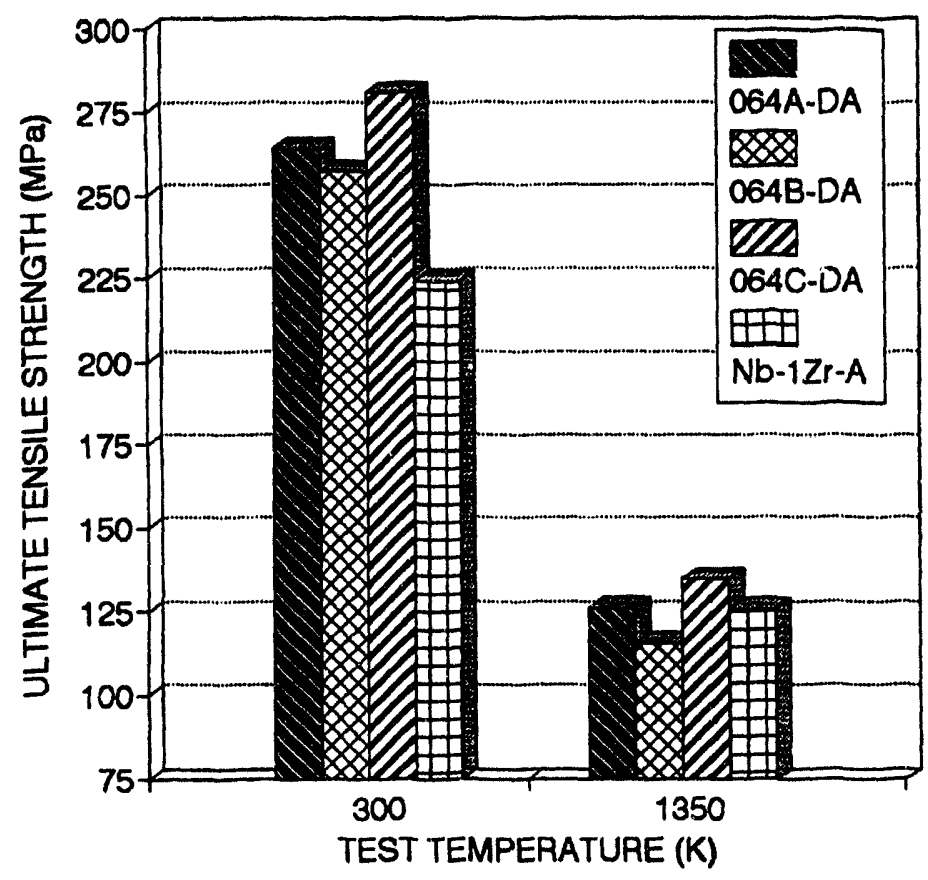

Figure 4.-Bar graphs showing the ultimate strength of samples from $\mathrm{Nb}-1 \mathrm{Zr}$ and $\mathrm{Nb}-1 \mathrm{Zr}-0.1 \mathrm{C}$ at 300 and $1350 \mathrm{~K}$.

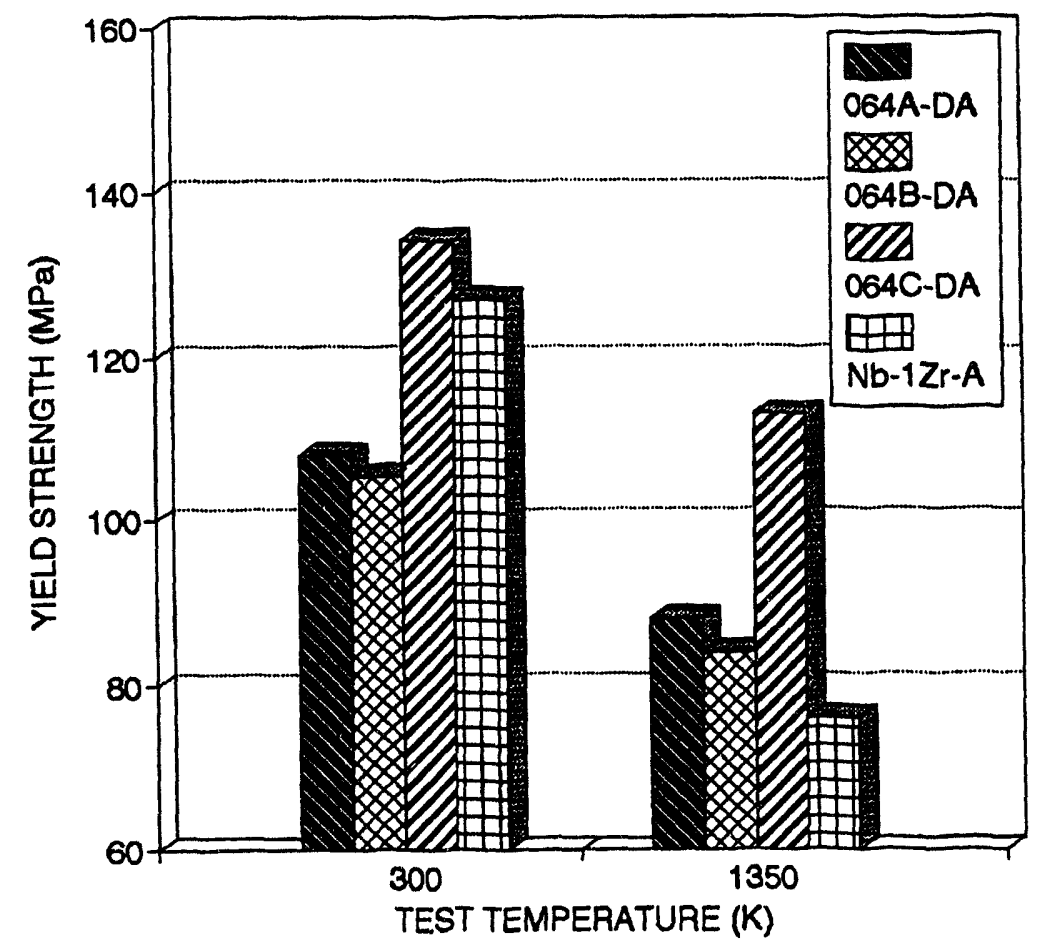

Figure 5. - Bar graphs showing the yield strength of samples from $\mathrm{Nb}-1 \mathrm{Zr}$ and $\mathrm{Nb}-1 \mathrm{Zr}-0.1 \mathrm{C}$ at 300 and $1350 \mathrm{~K}$. 


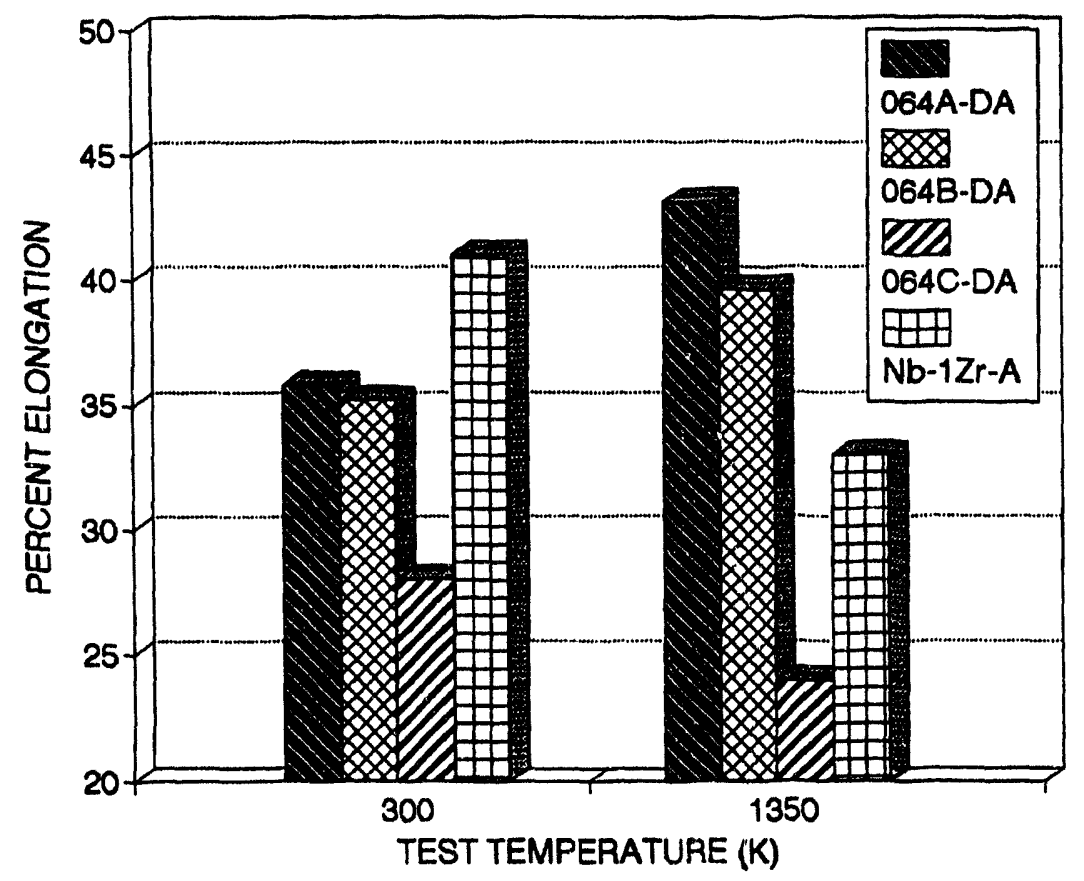

Figure 6.-Bar graphs showing the ductility of samples from $\mathrm{Nb}-1 \mathrm{Zr}$ and $\mathrm{Nb}-1 \mathrm{Zr}-0.1 \mathrm{C}$ at 300 and $1350 \mathrm{~K}$.

\section{Creep Properties}

The conditions and the results of the creep tests on various samples from $\mathrm{Nb}-1 \mathrm{Zr}, \mathrm{Nb}-1 \mathrm{Zr}-0.06 \mathrm{C}$ (LC-samples) and $\mathrm{Nb}-1 \mathrm{Zr}-0.1 \mathrm{C}$ (064-samples) are given in table $\mathrm{V}$. To better illustrate the creep behavior of each sample the results are plotted for the test conditions of $1350 \mathrm{~K}$ and $10 \mathrm{MPA}$ in figure $7,1350 \mathrm{~K}$ and $34.5 \mathrm{MPa}$ in figure 8 , and for $1450 \mathrm{~K}$ and $24 \mathrm{MPa}$ in figure 9. It will be noted that all the creep tests have been concluded with the exception of those at $1450 \mathrm{~K}$. These latter tests are still in progress at over $10,000 \mathrm{hr}$, and each appears to have reached the linear or steady state creep stage already (around $3000 \mathrm{hr}$ ).

The first four columns in table $\mathrm{V}$ are self explanatory. The total creep strain in each sample as measured at the time indicated is given in column 5. The steady state creep rate in column 6 is calculated from the slope of the linear portion of the strain-time plot for each sample. This rate is then used to estimate the time it would take each sample to reach 1 and 2 percent strain given in columns 7 and 8 , respectively. These times are given as a range with its lower and higher ends corresponding to the lower and higher ends of the \pm error in each. For samples which crept 1 or 2 percent during testing, the experimentally-determined times are provided in parentheses. It is noteworthy that the comparison of the experimental and estimated values for such samples shows that the estimated times to reach 1 or 2 percent strain are more conservative.

The results in table $\mathrm{V}$ and figure 7 for the creep tests at $1350 \mathrm{~K}$ and $10 \mathrm{MPa}$ show that $\mathrm{Nb}-1 \mathrm{Zr}$ DA10 reached a strain of 2 percent in less than $20,000 \mathrm{hr}$, and it crept over 4 percent after nearly 32,000 $\mathrm{hr}$ of testing. Of the carbon-containing alloys tested under similar conditions, LC-DA10 showed no measurable strain after $34,500 \mathrm{hr}$ and the total strain in LC-DA/AGE10 was about 0.1 percent after nearly $32,500 \mathrm{hr}$. The estimated time to reach 2 percent creep strain for either of the crept LC-samples was well over 25 years. Considering that LC-DA10 showed no measurable creep strain after 4 years of testing, this number may be quite realistic and perhaps even a little conservative. Furthermore, it was reported in the earlier studies (refs. 5 and 6) that the stress necessary to reach 1 percent strain in 7 years was about $4 \mathrm{~Pa}$ 
TABLE V. RESULTS OF THE CREEP TESTS AT $13.50 \mathrm{~K}$ AND $34.5 \mathrm{MPa}$ AND AT $1450 \mathrm{~K}$ AND $24 \mathrm{MPa}$

\begin{tabular}{|c|c|c|c|c|c|c|c|}
\hline \multirow[t]{2}{*}{ Sample } & \multicolumn{3}{|c|}{ Test conditions } & \multicolumn{2}{|c|}{ Test results } & \multicolumn{2}{|c|}{ Time to strainc } \\
\hline & $\begin{array}{c}\text { Time, } \\
\mathrm{hr}\end{array}$ & $\begin{array}{c}\text { Temperature, } \\
\text { K }\end{array}$ & $\begin{array}{c}\sigma, \\
\mathrm{MPa}\end{array}$ & $\underset{\%}{\text { Total } \varepsilon}$ & $\begin{array}{c}\text { Linear }^{\mathrm{b}} \\
\boldsymbol{\varepsilon}^{\circ} \\
\mathrm{h}^{-1}\end{array}$ & $\begin{array}{l}\varepsilon=1 \% \\
1000 \mathrm{hr}\end{array}$ & $\begin{array}{l}\varepsilon=2 \% \\
1000 \mathrm{hr}\end{array}$ \\
\hline $\mathrm{Nb}-1 \mathrm{Zr}-\mathrm{DA} 10$ & 31780 & 1350 & 10 & 4.06 & $(14 \pm 0.07) \times 10^{-5}$ & $\begin{array}{l}7.1-7.2 \\
(11)^{d}\end{array}$ & $\begin{array}{l}14.2-14.4 \\
(18)^{d}\end{array}$ \\
\hline LC-DA10 & 34500 & 1350 & 10 & (e) & (e) & (e) & (e) \\
\hline LC-DA/AGE10 & 32500 & 1350 & 10 & 0.1 & $(3.2 \pm 0.56) \times 10^{-6}$ & $266-378$ & $532-756$ \\
\hline $\mathrm{Nb}-1 \mathrm{Zr}-\mathrm{A} 34$ & 218 & 1350 & 34.5 & 5.18 & $(233 \pm 2.3) 10^{-5}$ & $\begin{array}{r}0.04-0.05 \\
(0.075)^{d}\end{array}$ & $\begin{array}{c}0.08-0.10 \\
(0.125)^{d}\end{array}$ \\
\hline LC-DA34 & 4288 & 1350 & 34.5 & 1.65 & $(39.7 \pm 5) \times 10^{-5}$ & $\begin{array}{c}2.30-2.90 \\
(3.2)^{\mathrm{d}}\end{array}$ & $4.6-5.8$ \\
\hline 064A-DA34 & 18780 & 1350 & 34.5 & 0.29 & $(11.6 \pm 1.7) 10^{-6}$ & $75.2-101$ & $150.4-272$ \\
\hline O64B-DA34 & 15460 & 1350 & 34.5 & 0.21 & $(14 \pm 0.8) \times 10^{-6}$ & $67.5-75.5$ & $135-15 i$ \\
\hline 064C-DA34 & 9950 & 1350 & 34.5 & 0.27 & $(17 \pm 1.1) 10^{-6}$ & $55-63$ & $110-126$ \\
\hline 064A-DA24 & 11800 & 1450 & 24 & 0.82 & $(64 \pm 2) \times 10^{-6}$ & $15.2-16.2$ & $30.4-32.4$ \\
\hline O64B-DA24 & 10000 & 1450 & 24 & 0.29 & $(16.1 \pm 2.5) 10^{-6}$ & $53.5-73.5$ & $107-147$ \\
\hline O64C-DA24 & 11100 & 1450 & 24 & 0.16 & $(9.7 \pm 1.4) \times 10^{-6}$ & $90-120$ & $180-240$ \\
\hline
\end{tabular}

${ }^{2}$ Creep test in progress.

blinear or steady-state creep rate as calculated from the slope of the strain versus time plot.

CEstimated using the linear strain rate in column 6.

dExperimental values as observed during the creep test.

'This sample had no measurable strain at the conclusion of the creep test.

for double-annealed $\mathrm{Nb}-1 \mathrm{Zr}$ alloy and $20 \mathrm{MPa}$ for a similarly heat-treated $\mathrm{Nb}-1 \mathrm{Zr}-0.06 \mathrm{C}$ alloy at $1350 \mathrm{~K}$. These results clearly indicate that the carbide-strengthened $\mathrm{Nb}-1 \mathrm{Zr}-0.06 \mathrm{C}$ alloy has much better creep resistance than the solid solution-strengthened $\mathrm{Nb}-1 \mathrm{Zr}$ alloy at $1350 \mathrm{~K}$ and $10 \mathrm{MPa}$.

The data in table $\mathrm{V}$ clearly shows that the creep resistance of the $\mathrm{Nb}-1 \mathrm{Zr}$ alloys containing carbon are superior to that without carbon at $1350 \mathrm{~K}$ and $34.5 \mathrm{MPa}$ as well. $\mathrm{Nb}-1 \mathrm{Zr}-\mathrm{A} 34$ had a total strain of over 5 percent in only $218 \mathrm{hr}$, and the total strain in the alloy with $0.06 \mathrm{C}$ (LC-DA34) was about 1.6 percent after nearly $4300 \mathrm{hr}$. The total strain in each of the samples from the $\mathrm{Nb}-1 \mathrm{Zr}-0.1 \mathrm{C}$ sheets was less than 0.3 percent after creep tests of nearly $19,000 \mathrm{hr}$ for $064 \mathrm{~A}-\mathrm{DA} 34,15,000 \mathrm{hr}$ for $064 \mathrm{~B}-\mathrm{DA} 34$, and 10,000 hr for 064C-DA34.

The creep plots in figure 8 would indicate that the creep behavior of the single-, double-, and triple-extruded sheets from the $\mathrm{Nb}-1 \mathrm{Zr}-0.1 \mathrm{C}$ alloy (064A-DA34, 064B-DA34, and 064C-DA34, respectively) are similar to one another at $1350 \mathrm{~K}$ and $34.5 \mathrm{MPa}$. It is evident from the figure and table $\mathrm{V}$, however, that each of these alloys has a much better creep resistance than either $\mathrm{Nb}-1 \mathrm{Zr}-\mathrm{A} 34$ or LC-DA34. The linear or steady state creep rate of the LC-DA34 is one order of magnitude and those of the 064-sheets are 


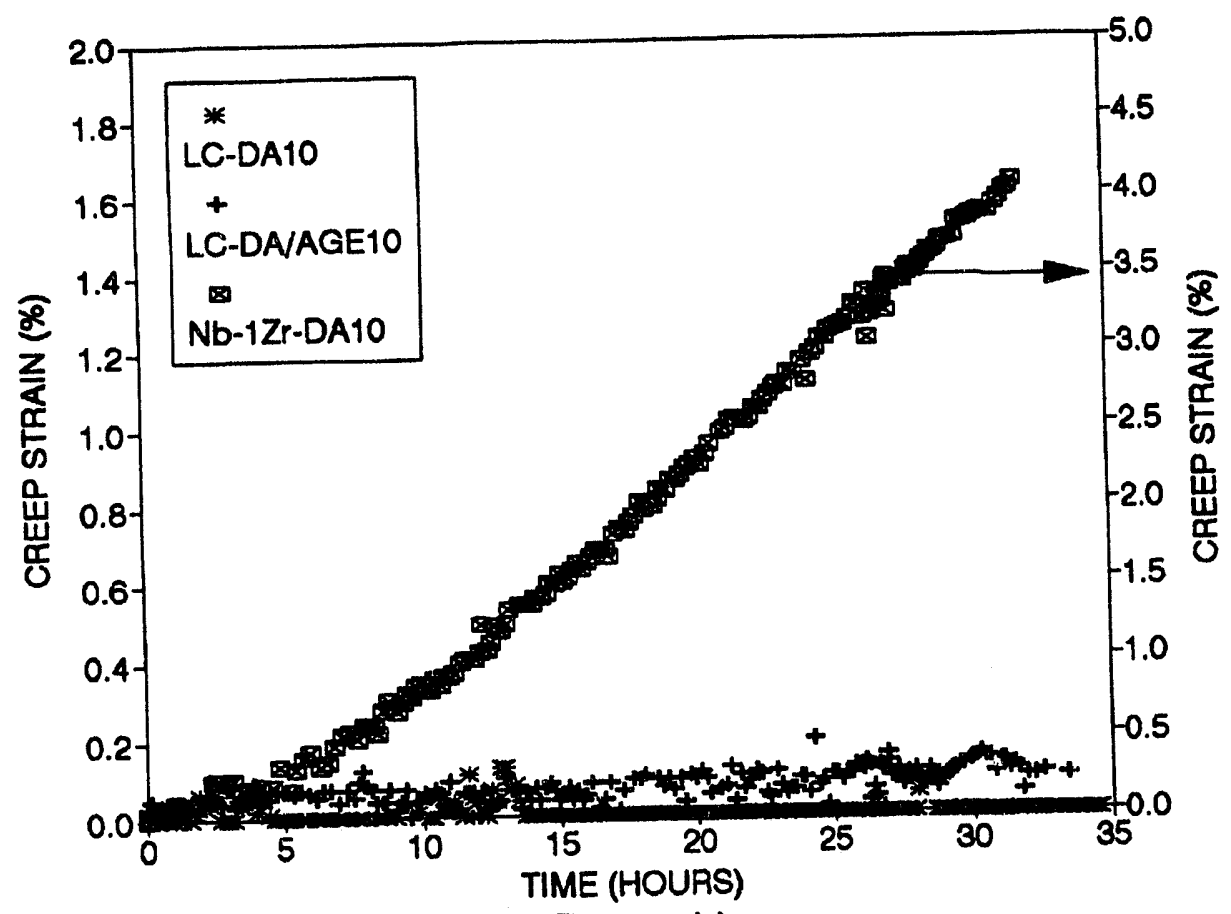

(Thousands)

Figure 7. - Strain versus time plots for samples from Nb-1Zr and Nb-1Zr-0.06C specimens creep tested at $1350 \mathrm{~K}$ and $10 \mathrm{MPa}$.The specimens were double-annealed (DA: $1 \mathrm{~h}$ at $1755 \mathrm{~K}+2 \mathrm{~h}$ at $1475 \mathrm{~K}$ ) or double-annealed and aged (AGE: $1000 \mathrm{~h}$ at $1350 \mathrm{~K}$ ) as indicated. (Read right strain axis for $\mathrm{Nb}-1 \mathrm{Zr}-\mathrm{DA} 10$. )

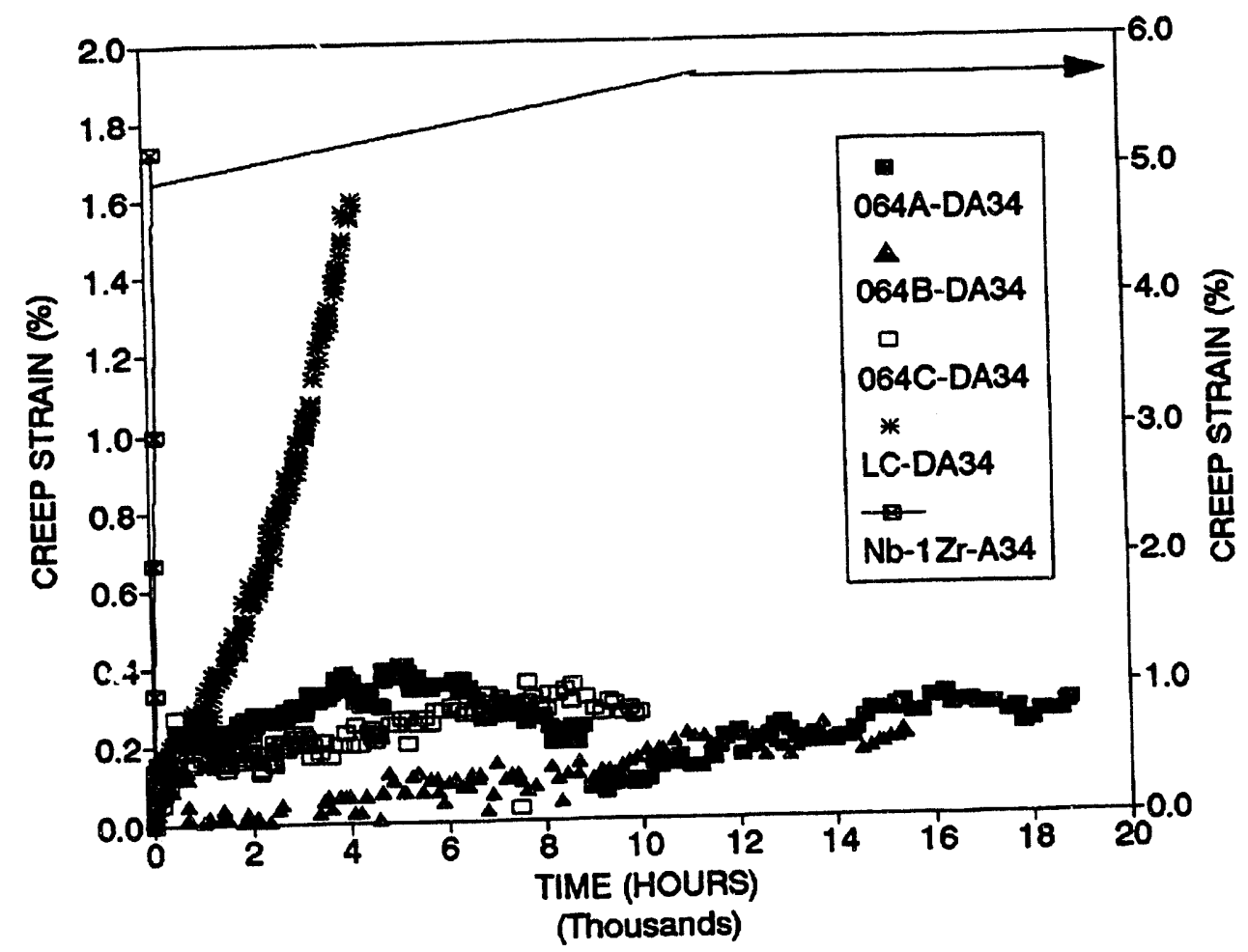

Figure 8. - Strain versus time plots for specimens from $\mathrm{Nb}-1 \mathrm{Zr}, \mathrm{Nb}-1 \mathrm{Zr}-0.06 \mathrm{C}$ and $\mathrm{Nb}-1 \mathrm{Zr}-0.1 \mathrm{C}$ creep tested at $1350 \mathrm{~K}$ and $34.5 \mathrm{MPa}$. (Read right strain axis for $\mathrm{Nb}-1 \mathrm{Zr}-\mathrm{A34}$.) 


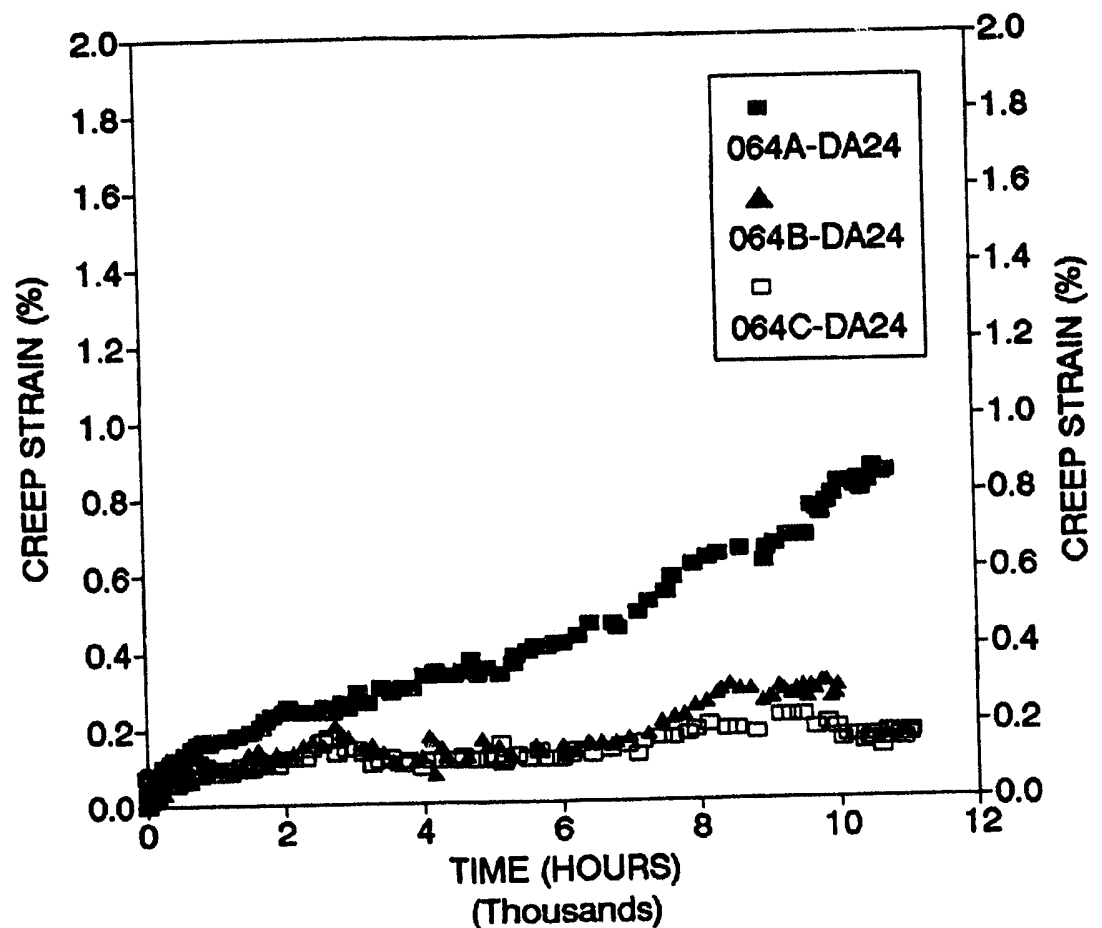

(Thousands)

Figure 9.-Strain versus time plots for specimens from $\mathrm{Nb}-1 \mathrm{Zr}-0.1 \mathrm{C}$ creep tested at $1450 \mathrm{~K}$ and $24 \mathrm{MPa}$.

at least two orders of magnitude less than the linear creep rate of the $\mathrm{Nb}-1 \mathrm{Zr}$ alloy. At $1350 \mathrm{~K}$ and 34.5 $\mathrm{MPa}$, the estimated time to reach a creep strain of 2 percent is around $100 \mathrm{hr}$ for $\mathrm{Nb}-1 \mathrm{Zr}-\mathrm{A} 34(\approx 125 \mathrm{hr}$ as measured during testing) and less than $6000 \mathrm{hr}$ for $\mathrm{Nb}-1 \mathrm{Zr}-0.06 \mathrm{C}$ sample LC-DA34. Under the same conditions, the $\mathrm{Nb}-1 \mathrm{Zr}-0.1 \mathrm{C}$ sheet with the highest creep rate (064C-DA34) is estimated to reach 2 percent strain in at least about $110,000 \mathrm{hr}$, approximately twice the design service life of $61,000 \mathrm{hr}$ (7 years). The data in table $\mathrm{V}$ would further indicate that of the $\mathrm{Nb}-1 \mathrm{Zr}-0.1 \mathrm{C}$ sheets, 064A-DA34 is the most and 064C-DA34 is the least creep resistant at $1350 \mathrm{~K}$.

The data from the creep tests that are in progress at $1450 \mathrm{~K}$ and $24 \mathrm{MPa}$ (see table $\mathrm{V}$ and fig. 9) show a somewhat different trend. Among these samples, 064C-DA24 appears to be the most and 064ADA24 the least creep resistant, which is a reversal of the order at $1350 \mathrm{~K}$ and $34.5 \mathrm{MPa}$. The total strain in 064A-DA24 is about 0.8 percent after nearly $11,000 \mathrm{hr}$, and its linear strain rate is anomalously high. This sheet is estimated to reach 2 percent strain in less than 4 years which is less than the service life requirement of 7 years. Of the other two samples being tested, the estimated time to reach 2 percent strain is about 12 years for 064B-DA24 and nearly 20 years for 064C-DA24.

It is evident from the creep data presented here that the carbide strengthened $\mathrm{Nb}-1 \mathrm{Zr}$ alloys have much better creep resistance than the solid solution-strengthened $\mathrm{Nb}-1 \mathrm{Zr}$ alloy at $1350 \mathrm{~K}$ and should be the case at $1450 \mathrm{~K}$ as well. This must be expected because of the presence of extremely stable cubic carbides of $(\mathrm{Zr}, \mathrm{Nb}) \mathrm{C}$ in the carbon-containing alloys. These carbides are shown to form during processing and especially during high-temperature exposure mainly as a result of transformation from rather coarse $\mathrm{Nb}_{2} \mathrm{C}$ (refs. 8 and 12). It is also obvious from the results that increasing the carbon content from 0.06 to 0.1 percent gives rise to a marked increase in the creep resistance of the alloy. This can be attributed to an increase in the number density of the carbides, because more carbon goes out of solution and become available for precipitation with increasing carbon content. Furthermore, it is quite clear that the carbidestrengthened alloys would be the only choices if a service life of 7 years with a total creep strain of less than 2 percent are to be required at temperatures around $1350 \mathrm{~K}$ and stresses approaching or exceeding $10 \mathrm{MPa}$. 


\section{CONCLUSIONS}

Microhardness, tensile, and long-term creep behavior of $\mathrm{Nb}-1 \mathrm{Zr}-0.1 \mathrm{C}$ sheets with different processing histories were studied. The sheets studied were fabricated by cold rolling following single-, double-, or triple-extrusion operations at $1900 \mathrm{~K}$. The purpose was to determine the effects of thermomechanical processing on the properties and to assess the feasibility of the use of these materials in advanced power system applications. From the results obtained in this study on the $\mathrm{Nb}-1 \mathrm{Zr}-0.1 \mathrm{C}$ sheets and the previous results on $\mathrm{Nb}-1 \mathrm{Zr}$ and $\mathrm{Nb}-1 \mathrm{Zr}-0.06 \mathrm{C}$ sheets, the following conclusions could be drawn:

1. The number of $1900 \mathrm{~K}$ extrusions prior to cold rolling does not have a significant effect on the micro-hardness of $\mathrm{Nb}-1 \mathrm{Zr}-0.1 \mathrm{C}$ sheets in a giveñ condition, e.g., as-rolled, as double annealed. Microhardness decreases $(\approx 40$ percent) significantly upon double annealing, but is not affected by subsequent exposure to $1350 \mathrm{~K}$ for as long as $19,000 \mathrm{hr}$.

2. The samples from the single-, double-, and triple-extruded $\mathrm{Nb}-1 \mathrm{Zr}-0.1 \mathrm{C}$ sheets (064A-DA, 064B-DA, and 064C-DA, respectively) and those of the $\mathrm{Nb}-1 \mathrm{Zr}$ alloy that was annealed for $1 \mathrm{~h}$ at $1475 \mathrm{~K}$ $(\mathrm{Nb}-1 \mathrm{Zr}-\mathrm{A})$ all have more than adequate strength and ductility for advanced power applications intended.

3. Multiple extrusions appear to have very little if any beneficial effect on the creep behavior of the $\mathrm{Nb}-1 \mathrm{Zr}-0.1 \mathrm{C}$ sheet at $1350 \mathrm{~K}$. At this temperature under either 10 or $34.5 \mathrm{MPa}$, the carbide-strengthened sheets containing 0.06 or $0.1 \% \mathrm{C}$ all have much superior creep resistance than the solid-solution strengthened $\mathrm{Nb}-1 \mathrm{Zr}$ owing to the presence of the extremely stable fine carbides of $\mathrm{Zr}$ and $\mathrm{Nb},(\mathrm{Zr}, \mathrm{Nb}) \mathrm{C}$. Furthermore, the creep resistance of the $\mathrm{Nb}-1 \mathrm{Zr}-\mathrm{C}$ alloy increases with increasing carbon content.

4. If a service life of 7 years with a total creep strain of 2 percent or less is desirable at $1350 \mathrm{~K}$, either of the carbon-containing alloys are viable candidates provided that the service stresses stay around $10 \mathrm{MPa}$. If the service stresses approach $34 \mathrm{MPa}$, the alloy with $0.1 \% \mathrm{C}$ should be the only choice, because at this stress level it takes $\mathrm{Nb}-1 \mathrm{Zr}$ a little over $100 \mathrm{hr}$ and $\mathrm{Nb}-1 \mathrm{Zr}-0.06 \mathrm{C}$ less than 1 year to reach 2 percent strain while the estimated time to creep 2 percent is over 12 years for $\mathrm{Nb}-1 \mathrm{Zr}-0.1 \mathrm{C}$.

\section{REFERENCES}

1. R.H. Cooper, Jr.: in Refractory Alloy Technology for Space Nuclear Power Applications, R.H. Cooper, Jr. and E.E. Hoffman, eds., Technical Information Center, U.S. Department of Energy, Oak Ridge, TN, 1984, pp. 14-17.

2. R.H. Titran: Advanced Materials and Processes, 1992, vol. 142, No. 5, pp. 34-41.

3. J.R. Lane; and G.M. Ault: Met. Engrg. Q., 1965, vol. 5, pp. 23-29.

4. R.W. Buckman, Jr. in Refractory Alloy Technology for Space Nuclear Power Applications, R.H. Cooper, Jr.; and E.E. Hoffman, eds., Technical Information Center, U.S. Department of Energy, Oak Ridge, TN, 1984, pp. 86-97.

5. R.H. Titran: NASA Report, No. TM-100142, NASA Lewis Research Center, Cleveland, OH, 1986.

6. R.H. Titran: NASA Report, No. TM-102390, NASA Lewis Research Center, Cleveland, OH, 1990. 
7. R.H. Titran; T.J. Moore; and T.L. Grobstein: NASA Report, No. TM-89834, NASA Lewis Research Center, Cleveland, OH, 1987.

8. M. Uz; and Titran: NASA Report, No. TM-103647, NASA Lewis Research Center, Cleveland, $\mathrm{OH}, 1991$.

9. E.J. DelGrosso; C.E. Carlson; and J.J. Kaminsky: J. Less-Common Metals, 1967, vol. 12, pp. 173201.

10. J.A. Horak; M.M. Paxton; and L.K. Egner: ORNL Report, No. ORNL/TM-11430, Office of Scientific and Technical Information, U.S. Department of Energy, Oak Ridge, TN, 1991.

11. R.W. Hall; and R.H. Titran: in Refractory Metals and Alloys III, R.I. Jaffee, ed., Gordon and Breach Science Publishers, New York, 1966, pp. 885-900.

12. J.F. Shackelford: Introduction to Materials Science for Engineers, Macmillan Publishing Co., New York, 1992, pp. 312-369.

13. M. Uz; and R.H. Titran: in AIP Conference Proceedings 271, M.S. El-Genk and M.D. Hoover, eds., DOE Conference 930103, American Institute of Physics, New York, 1993, pp. 69-83.

\section{ACKNOWLEDGMENTS}

This work was performed by the NASA Lewis Research Center for the U.S. DOE Office of Nuclear Energy and the Strategic Defense Initiative Office under interagency agreement DE-a103-86SF16310. 


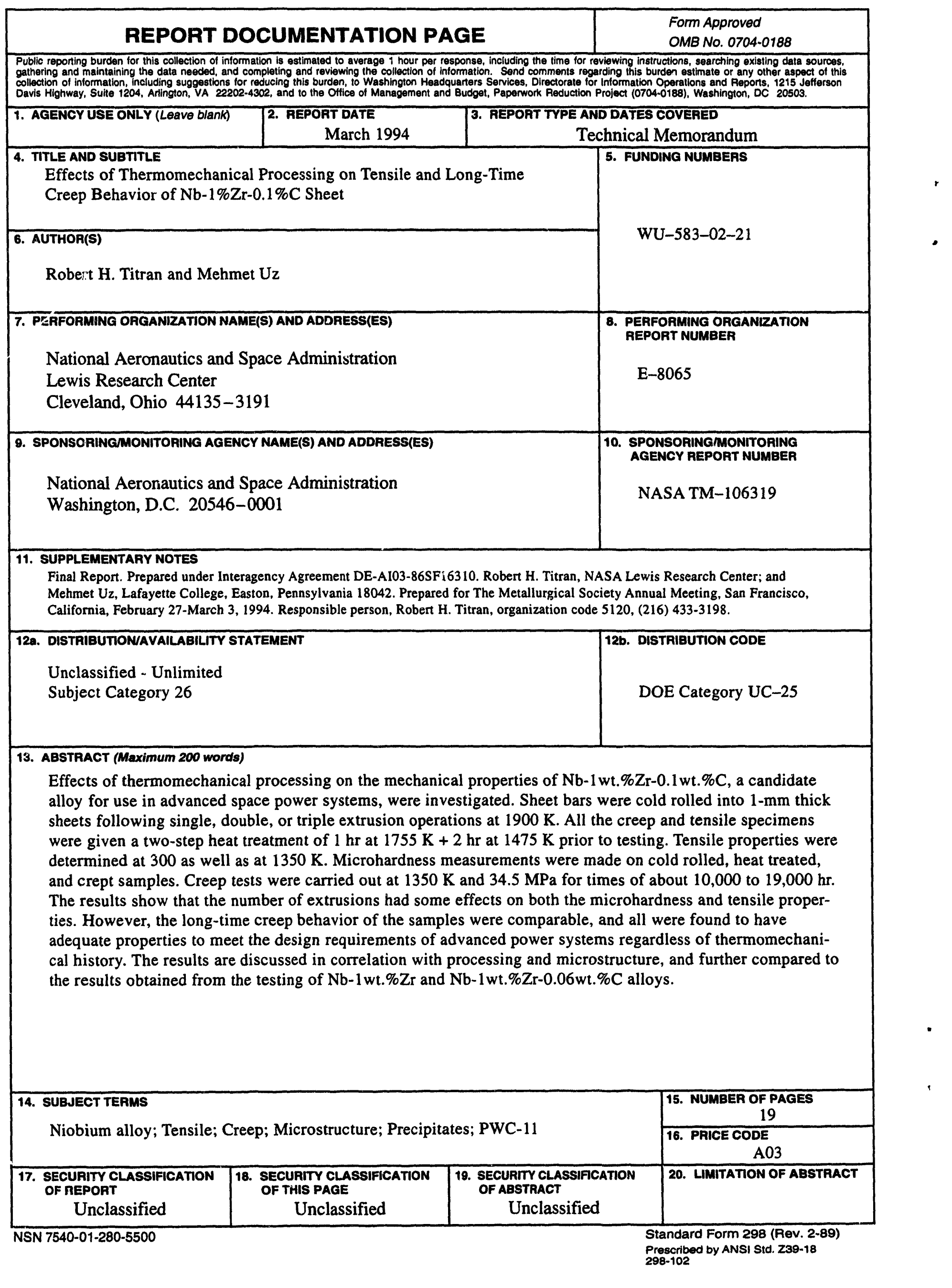



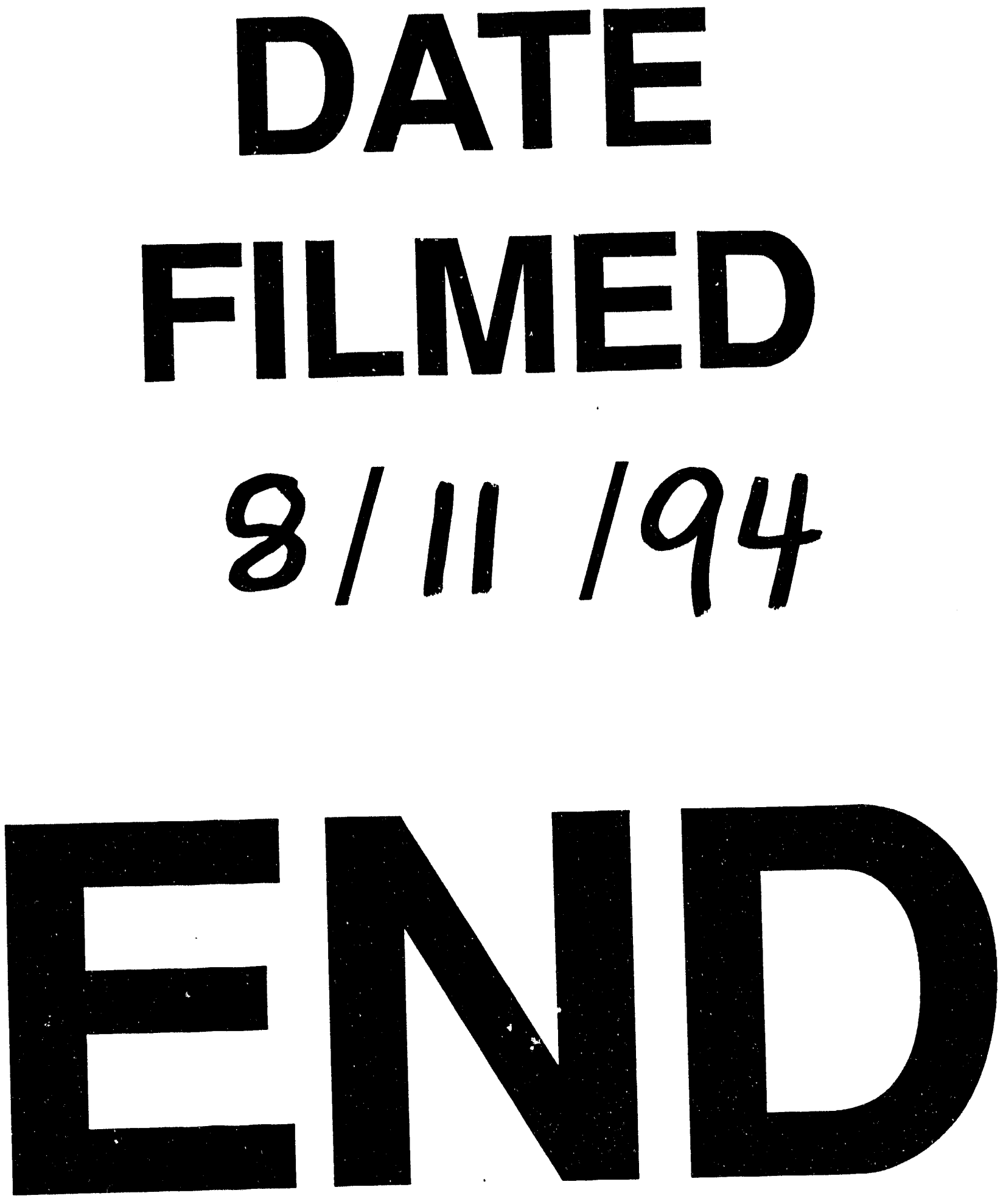


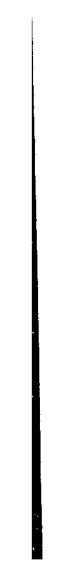

